\title{
Bioactivity of Hydrolysates Obtained from Chicken Egg Ovalbumin Using Artichoke (Cynara scolymus L.) Proteases
}

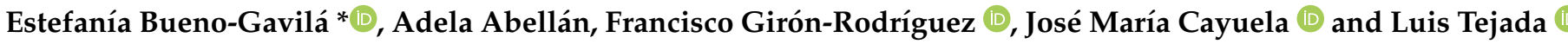 \\ Department of Human Nutrition and Food Technology, Universidad Católica de Murcia UCAM, \\ Campus de los Jerónimos, 30107 Guadalupe, Spain; aabellan@ucam.edu (A.A.); fgiron@ucam.edu (F.G.-R.); \\ jmcayuela@ucam.edu (J.M.C.); ltejada@ucam.edu (L.T.) \\ * Correspondence: ebueno@ucam.edu
}

Citation: Bueno-Gavilá, E.; Abellán, A.; Girón-Rodríguez, F.; Cayuela, J.M.; Tejada, L. Bioactivity of Hydrolysates Obtained from Chicken Egg Ovalbumin Using Artichoke (Cynara scolymus L.) Proteases. Foods 2021, 10, 246. https://doi.org/ $10.3390 /$ foods 10020246

Received: 18 December 2020

Accepted: 20 January 2021

Published: 26 January 2021

Publisher's Note: MDPI stays neutral with regard to jurisdictional claims in published maps and institutional affiliations.

Copyright: (C) 2021 by the authors Licensee MDPI, Basel, Switzerland. This article is an open access article distributed under the terms and conditions of the Creative Commons Attribution (CC BY) license (https:/ / creativecommons.org/licenses/by/ $4.0 /)$.

\begin{abstract}
The aim of this work was to obtain chicken egg ovalbumin hydrolysates using aspartic proteinases present in extracts from the artichoke flower (Cynara scolymus L.) and evaluate their antioxidant, antimicrobial, and angiotensin I-converting enzyme (ACE) inhibitory activity in vitro. Hydrolysis time and molecular weight $(<3 \mathrm{kDa})$ had a significant influence on the hypertensive and antioxidant activity of the hydrolysates. The $<3 \mathrm{kDa}$ fraction of the $16 \mathrm{~h}$ hydrolysate had an ACE inhibitory activity with an $\mathrm{IC}_{50}$ of $64.06 \mu \mathrm{g}$ peptides $/ \mathrm{mL}$. The fraction $<3 \mathrm{kDa}$ of ovalbumin hydrolysate at $2 \mathrm{~h}$ of hydrolysis showed a DPPH radical scavenging activity of $30.27 \mu \mathrm{M}$ of Trolox equivalents/mg peptides. The fraction $<3 \mathrm{kDa}$ of the hydrolysate of $16 \mathrm{~h}$ had an $\mathrm{ABTS}^{+}$caption activity of $4.30 \mathrm{mM}$ of Trolox equivalents $/ \mathrm{mg}$ peptides. The fraction $<3 \mathrm{kDa}$ of the hydrolysate of $2 \mathrm{~h}$ had an iron (II) chelating activity of $32.18 \mu$ g peptides $/ \mathrm{mL}$. From the peptide sequences identified in the hydrolysates, we detected four peptides (from the BIOPEP database) that were already in their bioactive form (IAAEVYEHTEGSTTSY, HLFGPPGKKDPV, PIAAEVYEHTEGSTTSY, and YAEERYPIL), and are reported to display antioxidant and ACE inhibitory activity.
\end{abstract}

Keywords: angiotensin-I converting enzyme (ACE) inhibitor; antioxidant; artichoke; bioactive peptide; ovalbumin

\section{Introduction}

Besides their elevated nutritional value, hen egg proteins or their derivatives show several biological activities, such as antioxidant activity, antihypertensive activity, antimicrobial activity, etc. [1]. Some of these proteins have activity by themselves, but the peptides derived from them, of between 2 and 20 amino acids, have shown a greater potential for bioactivity [2]. In addition to the length of the peptide chain, the amino acid composition also plays a very important role, with a higher bioactivity in peptides with hydrophobic amino acids having been observed [3]. Generally, in order for peptides to exert their bioactivity, they have to be cleaved from the sequence of their parent protein. The main procedure to obtain peptides with potential bioactivity from food proteins is enzymatic hydrolysis using different types of enzymes [4]. Generally, commercial enzymes are the most widely used because their characterization and activity are well-known [5]. Some of the enzymes most used in protein hydrolysis are pepsin, trypsin, alcalase, and papain [6-9], but the number of plant enzymes used is still limited, with enzymes of animal or microbial origin having mainly been used [10].

From the genus Cynara (e.g., thistle and artichoke), aspartic proteinases (cardosines and scolymines, respectively) that present high proteolytic activity can be obtained [11-13], giving rise to a large number of hydrophobic peptides [13-15] that have shown greater antioxidant [3,16,17] ACE inhibition [18] and antimicrobial activities [19].

The artichoke flower (Cynara scolymus) constitutes a very abundant agricultural byproduct in the Spanish southeast that can be used to obtain enzymatic extracts for the 
production of hydrolysates with potential bioactive peptides. These hydrolysates could be used as functional food ingredients or as natural antioxidants in food systems $[1,10]$.

Therefore, the objective of this work was to obtain ovalbumin hydrolysates with enzymatic extracts of artichoke flower. These hydrolysates have been analyzed for antioxidants, ACE-I inhibition, and antimicrobial activities in vitro. Additionally, the sequences of the peptides obtained have been identified and compared with those collected in the BIOPEP database [20].

\section{Materials and Methods}

\subsection{Obtaining the Enzymatic Extract of Cynara scolymus L.}

Mature artichoke flowers (Cynara scolymus L.) from the Murcia Region of Spain were used. To obtain the enzymatic extract, the methodology described by Tejada and Fernández Salguero (2003) [21] was followed. Briefly, the styles and stigmas of the artichoke flowers were trimmed and allowed to macerate in water $(1: 5 \mathrm{w} / \mathrm{v})$ for $24 \mathrm{~h}$. Then, the mash was sieved, and the aqueous extract was centrifuged $(4000 \times g$ for $5 \mathrm{~min})$ and filtered. The permeate obtained was lyophilized and frozen at $-20{ }^{\circ} \mathrm{C}$ until use.

\subsection{Obtaining the Hydrolysates}

The hydrolysis of commercial ovalbumin (Acros Organics) with the artichoke extract was developed using the optimal conditions previously studied [15]. For this, an ovalbumin solution of $1 \%(w / v)$ in distilled water at a $\mathrm{pH}$ of 6.2 was prepared. The reaction was performed in tubes submerged in a shaking bath at $36^{\circ} \mathrm{C}$ with an enzyme:substrate ratio of 0.0232 .

Ovalbumin hydrolysates were obtained at different hydrolysis times, $2(\mathrm{OH} 2), 4(\mathrm{OH} 4)$, and $16(\mathrm{OH} 16) \mathrm{h}$, to evaluate the effect of the hydrolysis time in obtaining peptides with bioactivity. The reaction was stopped at the corresponding time in each case, adjusting the $\mathrm{pH}$ to 4.5 with $\mathrm{HCl}$, the isoelectric point of ovalbumin that causes its precipitation, then, it was centrifuged for $20 \mathrm{~min}$ at $4000 \times g$ and filtered with a $0.45 \mu \mathrm{m}$ nylon filter. Finally, the hydrolysate obtained was raised to a $\mathrm{pH}$ of 7 with $\mathrm{NaOH}$, dispensed in Falcon tubes and reserved at $-20{ }^{\circ} \mathrm{C}$ until its utilization. Each type of hydrolysate was obtained in triplicate.

Furthermore, molecular weight fractions $<3 \mathrm{kDa}$ were obtained from each of the hydrolysates. For this, ultrafiltration was performed by centrifugation with Amicon Ultra-15 centrifuge filters of regenerated cellulose (3000 NML; Merck Millipore, Burlington, MA, USA) at $4{ }^{\circ} \mathrm{C}$ and at $4000 \times g$ for $40 \mathrm{~min}$. The permeate was collected in Falcon tubes at $-20{ }^{\circ} \mathrm{C}$ until use.

\subsection{Peptide Concentration}

The hydrolysate peptide concentration average was obtained by the Kjeldahl nitrogen quantification method [22], using the protein conversion factor of 6.7. Prior to the digestion of the sample, the precipitation of the protein residues that could remain in the sample was carried out by adding $5 \%$ trichloroacetic acid in a 1:2 $(v / v)$ proportion and centrifuging at $3200 \times \mathrm{g}$ for $20 \mathrm{~min}$. The peptide concentration was determined in triplicate for each type of hydrolysate.

\subsection{Determination of the Hydrophobicity of Peptides}

The concentration of hydrophilic and hydrophobic peptides of the hydrolysates was determined by reserve phase HPLC using the method described by González de Llano et al. (1994) [23]. The different nature of the peptides was estimated based on the retention time, considering hydrophobic peptides that appeared after the peak corresponding to the amino acid tryptophan (L-Trp $\geq 98 \%$, Sigma-Aldrich, Madrid, Spain), and hydrophilic peptides that appeared in the portion of peptides retained between the amino acid tyrosine (L-Tyr, $+99 \%$, Acros Organics, Fairlawn, NJ, USA) and the amino acid tryptophan. These determinations were conducted in triplicate for each type of hydrolysate. 


\subsection{Angiotensin I-Converting Enzyme Inhibitory Activity}

The angiotensin I-converting enzyme (ACE) inhibitory activity was determined by the method based on the spectrophotometric technique of Cushman and Cheung (1971) [24] adapted by Miguel et al. (2004) [25].

One hundred $\mu \mathrm{L}$ of substrate solution consisting of $5 \mathrm{mM}$ of hipuryl-histidyl-leucine (HHL; Sigma-Aldrich), dissolved in $0.1 \mathrm{M}$ of borate buffer and $0.3 \mathrm{M}$ of $\mathrm{NaCl}$ at a $\mathrm{pH}$ of 8.3 , was blended with $40 \mu \mathrm{L}$ of hydrolysate at a concentration of $125 \mu \mathrm{g}$ of peptides $/ \mathrm{mL}$. Two mU of ACE (EC 3.4.15.1., Sigma-Aldrich) was added, and the reaction was incubated for $30 \mathrm{~min}$ at $37^{\circ} \mathrm{C}$. After incubation, the enzyme was inactivated with $150 \mu \mathrm{L}$ of $\mathrm{HCl} 1 \mathrm{~N}$. The hippuric acid formed in the reaction was extracted by adding $1000 \mu \mathrm{L}$ of ethyl acetate. The blend was centrifuged at $4000 \times g$ for $10 \mathrm{~min}$, and $800 \mu \mathrm{L}$ of the organic phase was taken, which was subsequently placed on a heating plate for evaporation. The residue of hippuric acid formed was resuspended in $1000 \mu \mathrm{L}$ of distilled water, and the absorbance at $228 \mathrm{~nm}$ was measured. The ACE inhibition percentage was determined with the following formula:

ACE inhibitory activity $(\%)=(($ Acontrol - Ablank $)-($ Asample - Ablank $)) /($ Acontrol - Ablank $)) \times 100$

where Acontrol is the absorbance of hippuric acid formed during the reaction without inhibiting substances, Asample is the absorbance of hippuric acid formed in the reaction in the presence of the hydrolysate, and Ablank is the absorbance of HHL that has not reacted in distilled water. The assay was carried out in triplicate for each type of hydrolysate.

The half-maximal inhibitory concentration $\left(\mathrm{IC}_{50}\right)$ value is defined as the concentration of peptides required to inhibit $50 \%$ of the ACE activity. It was calculated for $\mathrm{OH} 16$, as well as its $<3 \mathrm{kDa}$ fraction using the concentration range of $25-125 \mu \mathrm{g}$ peptides $/ \mathrm{mL}$. The $\mathrm{IC}_{50}$ value was obtained in triplicate.

\subsection{Antioxidant Activity}

\subsubsection{DPPH Radical Scavenging Activity}

The DPPH (2,2-diphenyl-1-picrylhydrazyl (Sigma-Aldrich)) radical scavenging activity (RSA) was analyzed following the method described by Bersuder et al. (1998) [26], with slight modifications; $500 \mu \mathrm{L}$ of the hydrolysate was added to $625 \mu \mathrm{L}$ of DPPH $0.004 \%(w / v)$ in ethanol. The mixture was allowed to react for one hour in the dark at room temperature, and then it was centrifuged at $10,000 \times g$ for $2 \mathrm{~min}$. The absorbance of the supernatant was measured at $517 \mathrm{~nm}$. The percentage of antioxidant activity was determined applying this following formula:

DPPH RSA $(\%)=[(($ Acontrol - Ablank $)-($ Asample - Ablank $)) /($ Acontrol - Ablank $)] \times 100$

where Acontrol is the absorbance of the DPPH with water instead of hydrolysate, Asample is the absorbance of the radical DPPH in the presence of the hydrolysate, and Ablank is the absorbance of the blank (containing $50 \%$ of ethanol in distilled water $(v / v)$ ). The antioxidant activity against DPPH was calculated as the Trolox equivalent antioxidant capacity (TEAC; $\mu \mathrm{M}$ Trolox/mg of peptides). The experiment was conducted in triplicate for each type of hydrolysate.

\subsubsection{ABTS Radical Scavenging Activity}

The ABTS ((2,2'-azino-bis-(3-ethylbenzothiazoline-6-sulfonic acid) (Sigma, Aldrich)) radical scavenging activity of the hydrolysates was determined according to the method conducted by De Gobba et al. (2014) [27]. To create the radical $\left(\mathrm{ABTS}^{+}\right)$, a solution of ABTS $(19.4 \mathrm{mM})$ and potassium persulfate $(6.7 \mathrm{mM})$ in distilled water was allowed to react overnight. The $\mathrm{ABTS}^{+}$solution was reduced approximately 350 times with $10 \mathrm{mM}$ of phosphate buffer at a $\mathrm{pH}$ of 7.4 to reach an absorbance measure range at $405 \mathrm{~nm}$ of 0.6 to 0.7 .

To $200 \mu \mathrm{L}$ of the $\mathrm{ABTS}^{+}$working solution, $50 \mu \mathrm{L}$ of hydrolysate (at different concentrations) was added, and the absorbance was measured for $30 \mathrm{~min}$. The last measurements 
were used to calculate the percentage of antioxidant activity applying the following formula:

$$
\text { ABTS RSA }(\%)=100-[100 \times((\text { Asample }- \text { Ablank }) /(\text { Acontrol }- \text { Ablank }))]
$$

where Acontrol is the absorbance of the $\mathrm{ABTS}^{+}$solution with water instead of the sample, Abs sample is the absorbance of the $\mathrm{ABTS}^{+}$solution with hydrolysate, and Ablank is the absorbance of the blank (containing only the phosphate buffer). The half-maximal scavenging concentration $\left(\mathrm{SC}_{50}\right)$ was the peptide concentration necessary to scavenge $50 \%$ of the $\mathrm{ABTS}^{+}$. The $\mathrm{SC}_{50}$ was obtained using the sample concentration range of $2-20 \mu \mathrm{g}$ of peptides $/ \mathrm{mL}$. The TEAC value of the hydrolysates ( $\mathrm{mM}$ of Trolox equivalents $/ \mathrm{mg}$ of peptides) was also assessed. The assay was conducted in triplicate for each type of hydrolysate.

\subsubsection{Iron (II) Chelating Activity}

The iron (II) chelating activity was determined according to the method described by Wu et al. (2007) [28], with some modifications; $100 \mu \mathrm{L}$ of $75 \mu \mathrm{M} \mathrm{Cl}_{2} \mathrm{Fe}$ solution in distilled water was mixed with $25 \mu \mathrm{L}$ of the hydrolysate. The blend was incubated at room temperature for $10 \mathrm{~min}$. Then, $100 \mu \mathrm{L}$ of $500 \mu \mathrm{M}$ Ferrozine (3-(2-pyridyl)-5,6-dipjenyl1,2,4-triazine-p, $\mathrm{p}^{\prime}$-disulfonic acid) (Sigma, Aldrich) solution in water was added, and the absorbance was measured at $560 \mathrm{~nm}$. The inhibition of the iron-Ferrozine complex formation was calculated according to the following formula:

Iron chelating activity $(\%)=100-(100 \times($ Asample - Ablank $) /($ Acontrol - Ablank $))$

where Acontrol is the absorbance of the ferrozine complexed with iron without the hydrolysate, Asample is the absorbance of the ferrozine complexed in the presence of the hydrolysate, and Ablank is the absorbance of the blank (containing only distilled water). $\mathrm{IC}_{50}$ is defined as the peptide concentration necessary to inhibit $50 \%$ of the iron-Ferrozine complex formation. $\mathrm{IC}_{50}$ was calculated using a range of peptide concentrations of $11-83 \mu \mathrm{g}$ peptides $/ \mathrm{mL}$. The assay was conducted in triplicate for each type of hydrolysate.

\subsection{Antimicrobial Activity}

Antimicrobial activity was determined by comparing the bacterial growth curves following the method of Hill et al. (2013) [29], with some modifications described by BuenoGavilá et al. (2019) [30]. The bacterial species studied were Enterococcus faecalis (NCIMB 775), Escherichia coli (NCIMB 9484), Listeria innocua (CCUG 15531), and Pseudomonas fluorescens (NCIMB 9046). All of these species were acquired from the Spanish Type Culture Collection. The culture media used were peptone water (Pareac-Cultimed, Barcelona, Spain), tryptic soy broth (Scharlau, Sentmenat, Spain), and plate count agar (Scharlau). As a positive inhibition control, gentamicin (Sigma-Aldrich) of $\geq 95 \%$ purity was used. The curve data were processed using DMFit 3.5 according to the model of Baranyi and Roberts (1994), obtaining the most representative kinetic parameters (latency phase and maximum growth rate) and the maximum growth. The experiment was carried out in triplicate for each type of hydrolysate.

\subsection{Peptide Identification}

The identification of the peptides in the hydrolysates and the analysis of the bioactivity of these peptides identified were performed in the Proteomics and Bioinformatics units of the University of Córdoba (Spain). The peptide identification was carried out through nano-liquid chromatography-tandem MS analysis, performing a previous digestion with trypsin, following the methodology described in Bueno-Gavilá et al. 2019 [30].

For the analysis of the bioactivity in the peptides identified, the database of bioactive peptides, BIOPEP [20], was used. Two types of searches were carried out: the identification of the peptides in their bioactive form in the sample, and the identification of peptides with potential bioactivity, because they contain bioactive sequences in their primary structure. 
The analysis of the data obtained was executed using R (version 3.4.0; https:/ / www.rproject.org).

\subsection{Statistical Analysis}

Statistical analyses were performed using the SPSS program (version 21; IBM Corporation, Armonk, NY, USA). We performed ANOVA and Tukey tests to determine the hydrolysis time and molecular weight effect in the various defined parameters. In the study of the antibacterial activity of the hydrolysates, we used one-way ANOVA and the Dunnet test to identify differences between the means of the samples and the control, setting a confidence level of $95 \%$.

\section{Results}

\subsection{Total Peptides and Hydrophilic and Hydrophobic Peptides of Ovalbumin Hydrolysates}

The concentrations of each of the total hydrolysates (THs) and their fractions of molecular weight $<3 \mathrm{kDa}$ are shown in Table 1 . The hydrolysis time significantly affected the peptide concentration of the hydrolysates $(p<0.01)$, OH16 being the one that presented the highest concentration of peptides both in the TH and in its fraction $<3 \mathrm{kDa}$.

Table 1. Effect of hydrolysis time on the peptide concentration and hydrophobicity of ovalbumin hydrolysates from Cynara scolymus proteases. ${ }^{1}$

\begin{tabular}{|c|c|c|c|c|c|c|c|}
\hline \multirow{2}{*}{ Item $^{2}$} & & \multicolumn{3}{|c|}{ Hydrolysis Time (H) } & \multicolumn{3}{|c|}{$p$-Value ${ }^{3}$} \\
\hline & & 2 & 4 & 16 & $\mathbf{H}$ & MW & $\mathbf{H} \times \mathbf{M W}$ \\
\hline $\begin{array}{l}\text { Peptides } \\
(\mathrm{mg} / \mathrm{mL})\end{array}$ & $\begin{array}{c}\mathrm{TH} \\
<3 \mathrm{kDa}\end{array}$ & $\begin{array}{l}2.35 \pm 0.07^{\mathrm{c}} \\
1.31 \pm 0.07^{\mathrm{a}}\end{array}$ & $\begin{array}{l}2.50 \pm 0.04^{\mathrm{d}} \\
1.41 \pm 0.00^{\mathrm{a}}\end{array}$ & $\begin{array}{l}3.21 \pm 0.10^{\mathrm{e}} \\
2.08 \pm 0.04^{\mathrm{b}}\end{array}$ & $\leq 0.01$ & $\leq 0.01$ & $>0.05$ \\
\hline HI (\%) & $\begin{array}{c}\mathrm{TH} \\
<3 \mathrm{kDa}\end{array}$ & $\begin{array}{l}19.98 \pm 0.45^{b} \\
27.17 \pm 0.54^{a}\end{array}$ & $\begin{array}{l}23.27 \pm 0.17^{c} \\
44.32 \pm 0.97^{b}\end{array}$ & $\begin{array}{l}25.12 \pm 4.18^{c} \\
50.71 \pm 2.43^{b}\end{array}$ & $\leq 0.01$ & $\leq 0.01$ & $>0.05$ \\
\hline $\mathrm{HO}(\%)$ & $\begin{array}{c}\mathrm{TH} \\
<3 \mathrm{kDa}\end{array}$ & $\begin{array}{l}80.02 \pm 5.64^{b} \\
72.83 \pm 1.91^{a}\end{array}$ & $\begin{array}{l}76.73 \pm 6.03^{c} \\
55.68 \pm 0.97^{a}\end{array}$ & $\begin{array}{l}74.88 \pm 9.92^{b} \\
49.29 \pm 8.75^{a}\end{array}$ & $\leq 0.05$ & $\leq 0.01$ & $\leq 0.05$ \\
\hline $\mathrm{HO} / \mathrm{HI}$ & $\begin{array}{c}\mathrm{TH} \\
<3 \mathrm{kDa}\end{array}$ & $\begin{array}{l}4.01 \pm 0.25^{\mathrm{d}} \\
2.68 \pm 0.06^{\mathrm{b}}\end{array}$ & $\begin{array}{c}3.30 \pm 0.23^{b c} \\
1.26 \pm 0.04^{a}\end{array}$ & $\begin{array}{c}2.98 \pm 0.98^{b c} \\
0.97 \pm 0.13^{a}\end{array}$ & $\leq 0.05$ & $\leq 0.01$ & $>0.05$ \\
\hline
\end{tabular}

${ }^{a-d}$ Values within a row with distinct superscript letters were significantly different (LSD test, $\left.p<0.05\right)$. ${ }^{1}$ Values represent the mean $\pm \mathrm{SE}(n=3) .{ }^{2}$ Less than $3 \mathrm{kDa}=$ hydrolysate fraction on molecular eight $<3 \mathrm{kDa} ; \mathrm{HI}=$ hydrophilic peptides; $\mathrm{HO}=$ hydrophobic peptides; $\mathrm{HO} / \mathrm{HI}=$ hydrophobic and hydrophilic peptide ratio. ${ }^{3} \mathrm{H}=$ hydrolysis time; $\mathrm{MW}=$ molecular weight; $\mathrm{H} \times \mathrm{MW}=$ hydrolysis time $\times$ molecular weight interaction.

The hydrolysis time significantly affected the ratio of hydrophobic $(\mathrm{HO})$ and hydrophilic $(\mathrm{HI})$ peptides $(\mathrm{HO} / \mathrm{HI})$ of the ovalbumin hydrolysates $(p<0.05)$. The $\mathrm{OH} 2$, both in its $\mathrm{TH}$ and in the $<3 \mathrm{kDa}$ fraction, was the one with the highest $\mathrm{HO} / \mathrm{HI}$ ratio $(4.01 \pm 0.25 \%$ and $2.68 \pm 0.06 \%$, respectively). There were no significant differences in the $\mathrm{HO} / \mathrm{HI}$ ratio between the $\mathrm{OH} 4$ and $\mathrm{OH} 16$ for both the $\mathrm{THs}$ and their $<3 \mathrm{kDa}$ fractions.

\subsection{ACE Inhibitory Activity}

Figure 1 shows the ACE inhibitory activity percentages of the ovalbumin hydrolysates with Cynara scolymus extract, both of the THs and their $<3 \mathrm{kDa}$ fractions at a concentration of $125 \mu \mathrm{g} / \mathrm{mL}$.

The hydrolysis time in general did not significantly influence the ACE inhibitory activity of ovalbumin hydrolysates $(p>0.05)$, although $\mathrm{TH}, \mathrm{OH} 4$, and $\mathrm{OH} 16$ showed greater activity $(86.07 \pm 0.99 \%$ and $86.78 \pm 1.75 \%$, respectively) than $\mathrm{OH} 2(79.64 \pm 0.06 \%)$ $(p \leq 0.05)$. In the molecular weight fractions $<3 \mathrm{kDa}$, there were no significant differences in the ACE inhibitory activity between the different hydrolysis times $(p>0.05)$.

The molecular size of the peptides had a significant influence on the ACE inhibitory activity ( $p \leq 0.01$ ), with the $<3 \mathrm{kDa}$ fractions of the hydrolysates showing the highest percentage of inhibition in all of the cases, although no significant statistical differences $(p>0.05)$ were observed between the ACE inhibitory activity of the $\mathrm{OH} 4 \mathrm{TH}$ and the 
OH16 TH ( $86.07 \pm 0.99 \%$ and $86.78 \pm 1.75 \%$, respectively) and their fractions $<3 \mathrm{kDa}$ (87.55 $\pm 2.63 \%$ and $89.87 \pm 0.21 \%$, respectively).

$\mathrm{OH} 16$ and its fraction $<3 \mathrm{kDa}$ had an $\mathrm{IC}_{50}$ value of $69.55 \pm 3.12 \mu \mathrm{g} / \mathrm{mL}$ and $64.04 \pm$ $0.37 \mu \mathrm{g} / \mathrm{mL}$, respectively.

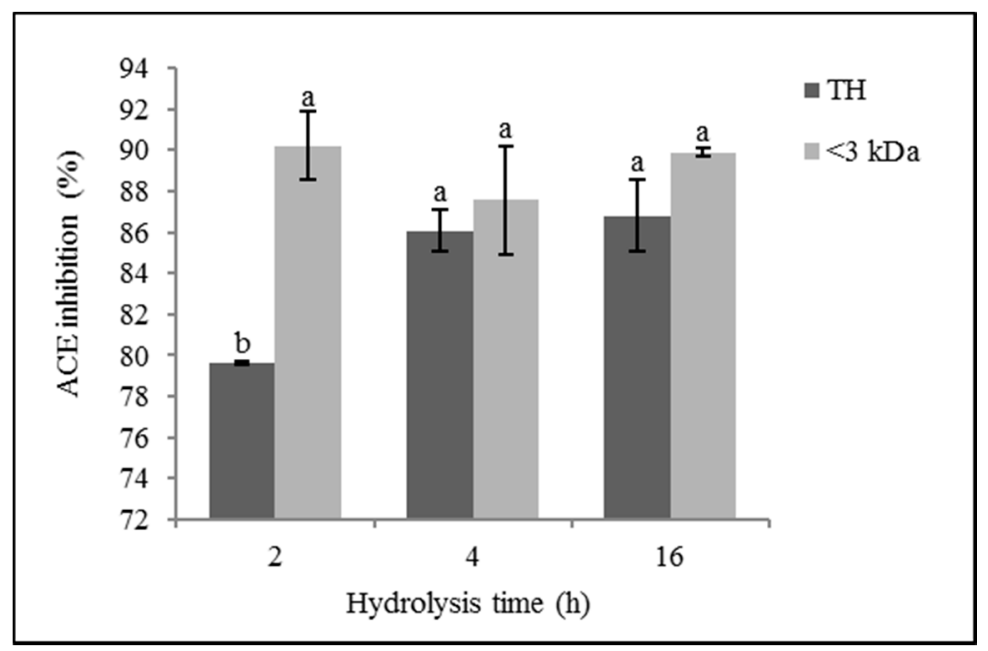

Figure 1. Angiotensin I-converting enzyme (ACE) inhibitory activity (\%) of ovalbumin total hydrolysates (THs) and their low molecular weight fractions $(<3 \mathrm{kDa})$. Values are means \pm SEs $(n=3)$. Bars with distinct letters $(\mathrm{a}, \mathrm{b})$ were significantly different (LSD test, $p<0.05)$.

\subsection{Antioxidant activity}

\subsubsection{DPPH Radical Scavenging Activity}

The results of the antioxidant activity of ovalbumin hydrolysates against the DPPH radical are shown in Figure 2. The hydrolysis time significantly affected the antioxidant activity of the hydrolysates against the DPPH radical $(p \leq 0.01)$.

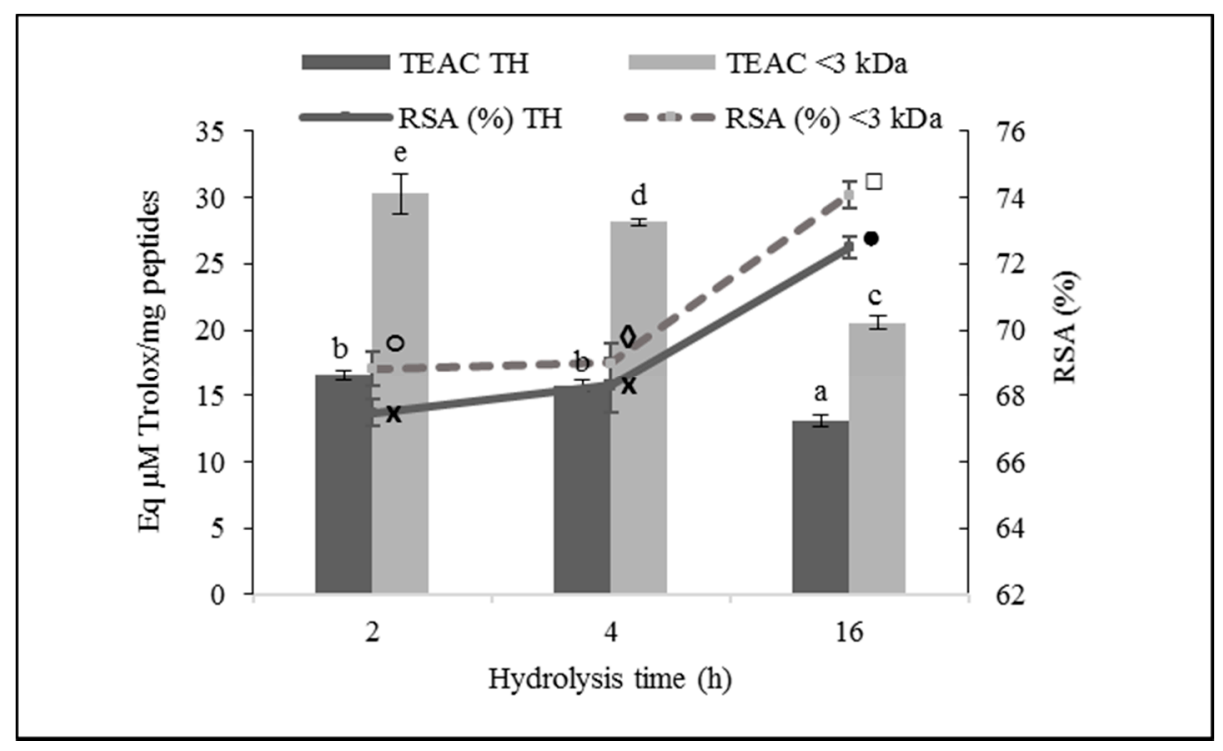

Figure 2. 2,2-Diphenyl-1-pycrylhydrazyl (DPPH) radical scavenging activity (RSA) of total ovalbumin hydrolysates (THs) and their low molecular weight fractions $(<3 \mathrm{kDa})$. Bars show the Trolox equivalent antioxidant capacity (TEAC; $\mu \mathrm{M}$ of Trolox equivalents per mg of peptides), and lines represent the percentage of RSA. Values are means \pm SEs $(n=3)$. Bars with distinct letters $(\mathrm{a}-\mathrm{e})$ and lines with distinct symbols $(\bullet, \times, \square, \diamond, \bigcirc)$ were significantly different (LSD test, $p<0.05$ ). 
Taking into account the percentage of DPPH RSA of the hydrolysates, the activity increased with the hydrolysis time $(p \leq 0.05)$. This must be due to the higher peptide concentration of the hydrolysates at a longer hydrolysis time. Paying attention to the Trolox $(\mu \mathrm{M})$ equivalent antioxidant capacity per $\mathrm{mg}$ of peptides, the antioxidant capacity decreased with the hydrolysis time, with $\mathrm{OH} 2$ being the most powerful hydrolysate in the uptake of the DPPH radical, with a TEAC value of $16.54 \mu \mathrm{M}$ of Trolox $/ \mathrm{mg}$ of peptides.

The molecular weight of the peptides also significantly affected the DPPH RSA of the ovalbumin hydrolysates $(p \leq 0.05)$, with the fraction $<3 \mathrm{kDa}$ being more potent than the $\mathrm{TH}$ at the three hydrolysis times. Considering the percentage of DPPH RSA, OH16 $<3 \mathrm{kDa}$ was the sample that presented the highest activity, with $74.09 \pm 0.40 \%$ of radical caption, however, attending at TEAC, $\mathrm{OH} 2<3 \mathrm{kDa}$ was the most powerful sample, with a value of $30.27 \pm 1.51 \mu \mathrm{M}$ of Trolox $/ \mathrm{mg}$ of peptides.

\subsubsection{ABTS Radical Scavenging Activity}

Hydrolysis time significantly affected the antioxidant activity of ovalbumin hydrolysates with $C$. scolymus L. against the ABTS radical $(p \leq 0.01)$, producing a decline in the $\mathrm{IC}_{50}$ value and, concurrently, a rise in the TEAC, indicating a higher antioxidant power of the hydrolysates (Figure 3). Thus, $\mathrm{OH} 16$ and its fraction $<3 \mathrm{kDa}$ was the hydrolysate with the highest antioxidant capacity against the ABTS radical $(p \leq 0.05)$, presenting an $\mathrm{IC}_{50}$ of $6.92 \pm 0.14$ and $6.65 \pm 0.04 \mu \mathrm{g} / \mathrm{mL}$, respectively. Nonetheless, molecular size did not affect the ABTS RSA of the ovalbumin hydrolysates $(p>0.05)$.

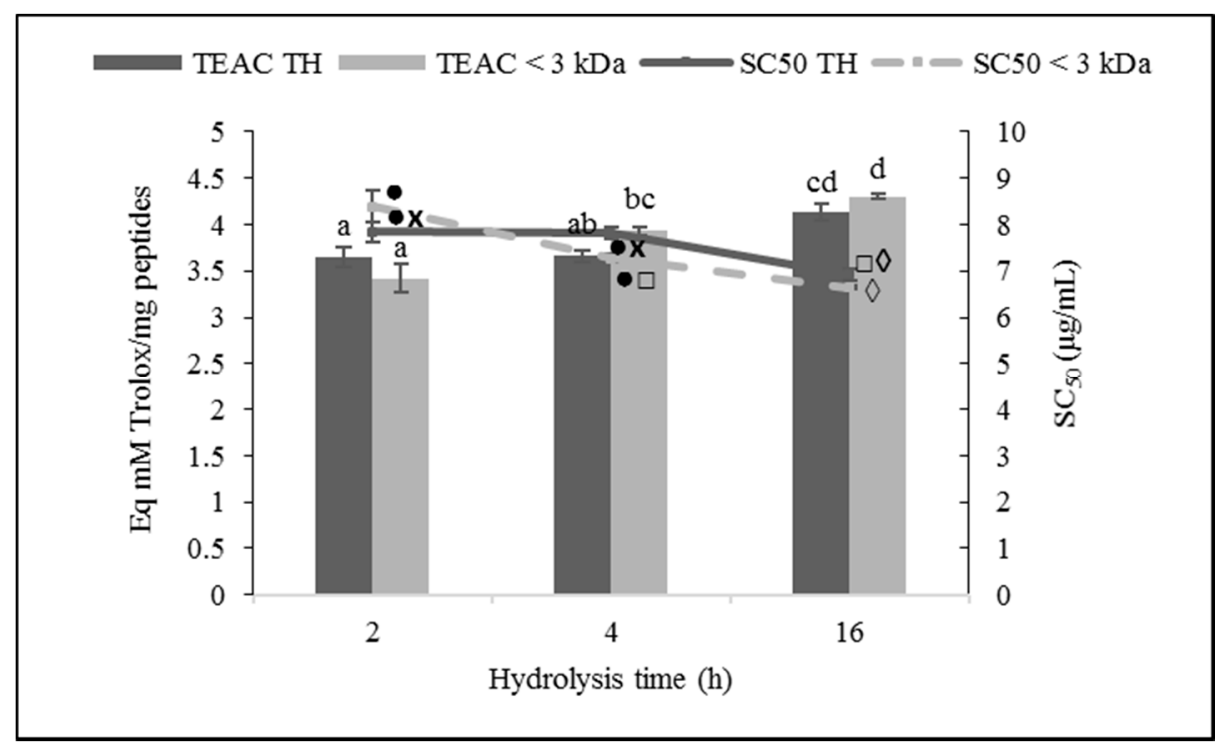

Figure 3. 2,2'-Azino-bis-(3-ethylbenzothiazoline-6-sulfonic acid) (ABTS) radical scavenging activity (RSA) of ovalbumin total hydrolysates (THs) and their low molecular weight fractions ( $<3 \mathrm{kDa})$. Bars show the Trolox equivalent antioxidant capacity (TEAC; $\mathrm{mM}$ of Trolox equivalents per mg of peptides), and lines represent the half-maximal scavenging concentration $\left(\mathrm{SC}_{50} ; \mu \mathrm{g} / \mathrm{mL}\right)$. Values are means \pm SEs $(n=3)$. Bars with distinct letters $(a-d)$ and lines with distinct symbols $(\bullet, \times, \square, \diamond)$ were significantly different (LSD test, $p<0.05)$.

\subsubsection{Iron (II) Chelating Activity}

The iron (II) chelating capacity of the ovalbumin hydrolysates obtained with the artichoke flower extract is shown in Figure 4. Regarding the effect of the hydrolysis time in the iron chelating activity of the $\mathrm{TH}$, no significant differences were observed $(p \geq 0.05)$. Nonetheless, considering the $<3 \mathrm{kDa}$ fractions of the hydrolysates, the chelating capacity decreased significantly with the hydrolysis time $(p \leq 0.05)$, with $\mathrm{OH} 2<3 \mathrm{kDa}$ being the sample that presented the highest $\mathrm{Fe}^{2+}$ chelating activity, with an $\mathrm{IC}_{50}$ value of $32.18 \mu \mathrm{g} / \mathrm{mL}$. Precisely, $\mathrm{OH} 2<3 \mathrm{kDa}$ presented the highest ratio of $\mathrm{HO} / \mathrm{HI}$ peptides. 
The molecular weight of the peptides significantly affected the iron (II) chelating activity $(p \leq 0.01)$, with the $<3 \mathrm{kDa}$ fractions showing the highest chelating potency $(p \leq 0.05)$. However, in the case of OH16, no significant differences $(p>0.05)$ were found between TH and its fraction $<3 \mathrm{kDa}$.

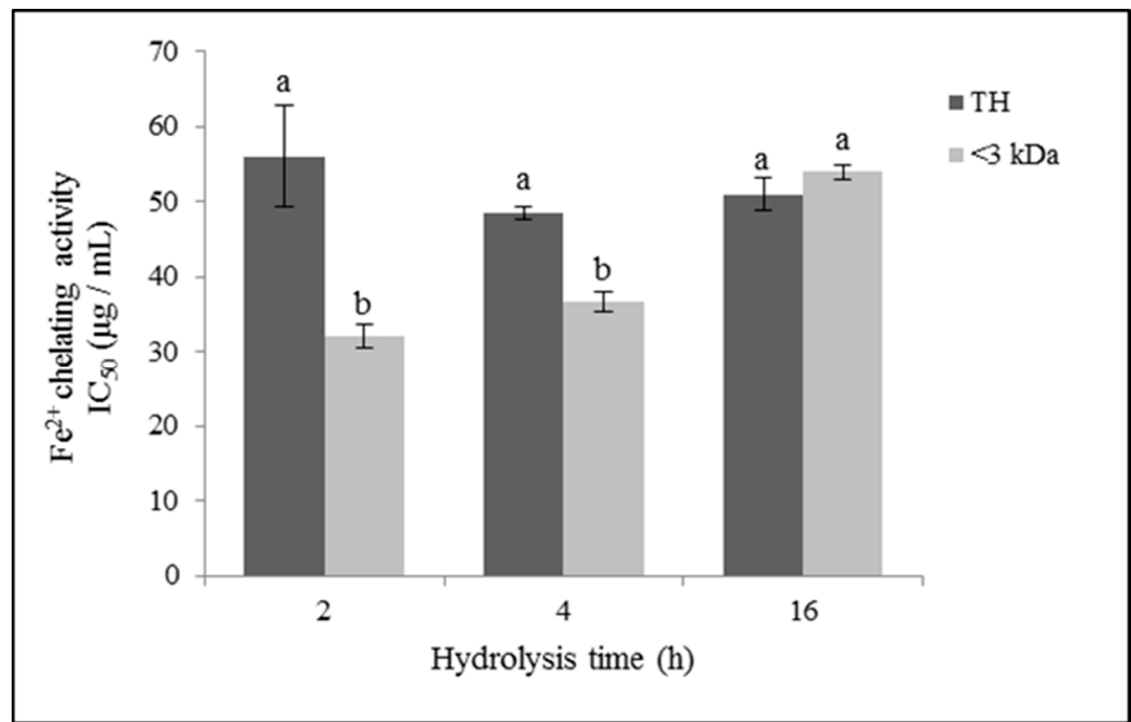

Figure 4. Iron (II) chelating activity (half-maximal inhibitory concentration $\left(\mathrm{IC}_{50}\right) ; \mu \mathrm{g} / \mathrm{mL}$ )) of ovalbumin total hydrolysates (THs) and their low molecular weight fractions $(<3 \mathrm{kDa})$. Values represent means \pm SEs $(n=3)$. Bars with distinct letters $(a, b)$ were significantly different (LDS test, $p<0.05)$.

\subsection{Antimicrobial Activity}

Analyzing the effect of the hydrolysates on the growth of the Gram negative microorganisms tested, only a statistically significant inhibitory effect was observed $(p \leq 0.05)$ for the growth rate of $E$. faecalis with $\mathrm{OH} 2 \mathrm{TH}$ and with the $<3 \mathrm{kDa}$ fractions at the different hydrolysis times (Table 2). However, the lag phase was shortened $(p \leq 0.01)$, and there were no changes in the maximum growth of the microorganism $(p>0.05)$. Regarding E. coli, no antimicrobial effect of the hydrolysates was detected on the growth curves. There was no antimicrobial effect of the hydrolysates against the Gram positive microorganisms tested, L. innocua and $p$. fluorescens (data not shown).

Table 2. Enterococcus faecalis antibacterial activity (in absorbance units, UAbs) of ovalbumin hydrolysates for Cynara scolymus proteases. $^{1}$

\begin{tabular}{|c|c|c|c|c|c|}
\hline \multirow{2}{*}{$\mathrm{MW}^{2}$} & \multirow{2}{*}{ Parameters } & \multirow{2}{*}{ Control } & \multicolumn{3}{|c|}{ Hydrolysis Time (h) } \\
\hline & & & 2 & 4 & 16 \\
\hline \multirow{3}{*}{$\mathrm{TH}$} & Lag phase (min) & $719.78 \pm 15.7$ & $586.74 \pm 8.2^{* *}$ & $598.00 \pm 12.6^{* *}$ & $648.94 \pm 12.7$ \\
\hline & Growth rate (mU Abs/min) & $3.73 \pm 0.2$ & $2.96 \pm 0.2 *$ & $3.15 \pm 0.2$ & $3.79 \pm 0.2$ \\
\hline & Maximum growth (U Abs) & $0.566 \pm 0.03$ & $0.579 \pm 0.01$ & $0.581 \pm 0.01$ & $0.551 \pm 0.01$ \\
\hline \multirow{3}{*}{$<3 \mathrm{kDa}$} & Lag phase (min) & $719.78 \pm 15.7$ & $554.50 \pm 10.24 * *$ & $574.88 \pm 14.0$ ** & $614.04 \pm 21.2^{* *}$ \\
\hline & Growth rate (mU Abs/min) & $3.73 \pm 0.2$ & $2.50 \pm 0.1^{* *}$ & $2.65 \pm 0.2^{* *}$ & $2.88 \pm 0.2^{* *}$ \\
\hline & Maximum growth (U Abs) & $0.566 \pm 0.03$ & $0.555 \pm 0.00$ & $0.557 \pm 0.01$ & $0.535 \pm 0.01$ \\
\hline
\end{tabular}

${ }^{1}$ Values represent means \pm SEs $(n=3) .{ }^{2} \mathrm{MW}=$ molecular weight, $\mathrm{TH}=$ total hydrolysate; $<3 \mathrm{kDa}=$ hydrolysate fraction of molecular weight $<3 \mathrm{kDa}$. ${ }^{*}{ }^{* *}$ Samples and control were significantly different (Dunnett test, ${ }^{*}=p<0.05 ;{ }^{* *}=p<0.01$ ).

\subsection{Identification of the Bioactive Peptides Present in the Oovalbumin Hydrolysates}

Table 3 shows the sequences of peptides from the ovalbumin hydrolysates, in their bioactive form, that have demonstrated biological activity. The identified peptide sequences common to the three types of ovalbumin hydrolysates $(2,4$, and $16 \mathrm{~h})$ that have 
demonstrated bioactivity are IAAEVYEHTEGSTTSY with antioxidant activity [31] and YAEERYPIL with ACE inhibitory activity [32]. On the other hand, non-shared peptides have been identified in OH2 and H4: PIAAEVYEHTEGSTTSY with antioxidant activity [31] and HLFGPPGKKDPV with ACE inhibitory activity [33], respectively.

Table 3. Peptide sequences identified in ovalbumin hydrolysates from Cynara scolymus proteases that were registered in the bioactive peptide database BIOPEP.

\begin{tabular}{ccccc}
\hline Sequence (Origin Hydrolysate) & ID & Origin & MM & Activity \\
\hline HLFGPPGKKDPV $(4 \mathrm{~h})$ & 8393 & Ovotransferrin & 1291.50 & ACE-inhibitor \\
IAAEVYEHTEGSTTSY $(2 \mathrm{~h}, 4 \mathrm{~h}, 16 \mathrm{~h})$ & 8235 & Ovotransferrin & 1757.81 & Antioxidative \\
PIAAEVYEHTEGSTTSY $(2 \mathrm{~h})$ & 8231 & Ovotransferrin & 1854.93 & Antioxidative \\
YAEERYPIL $(2 \mathrm{~h}, 4 \mathrm{~h}, 16 \mathrm{~h})$ & 8391 & Ovalbumin & 1153.28 & ACE-inhibitor \\
\hline
\end{tabular}

$\mathrm{ID}=\mathrm{BIOPEP}$ sequence identification number; $\mathrm{MM}=$ molecular mass $(\mathrm{Da})$.

On the other hand, in the ovalbumin hydrolysates with C. scolymus L. flower extract, peptides with possible potential biological activity have been identified, since encrypted sequences that have demonstrated bioactivity have been found within their primary structure. Figure 5 shows the distribution of the peptides with putative activity present in the ovalbumin hydrolysates at the three hydrolysis times. At all hydrolysis times, peptides containing sequences with bioactivity were obtained. OH4 yielded the highest amount of peptides with fragments with bioactivity, highlighting antioxidant activity, hypotensive activity, inhibition of dipeptidyl peptidase IV activity, activation of proteolysis mediated by ubiquitin activity, stimulant activity, opioid activity, and peptides with sequences that work as neuropeptides.

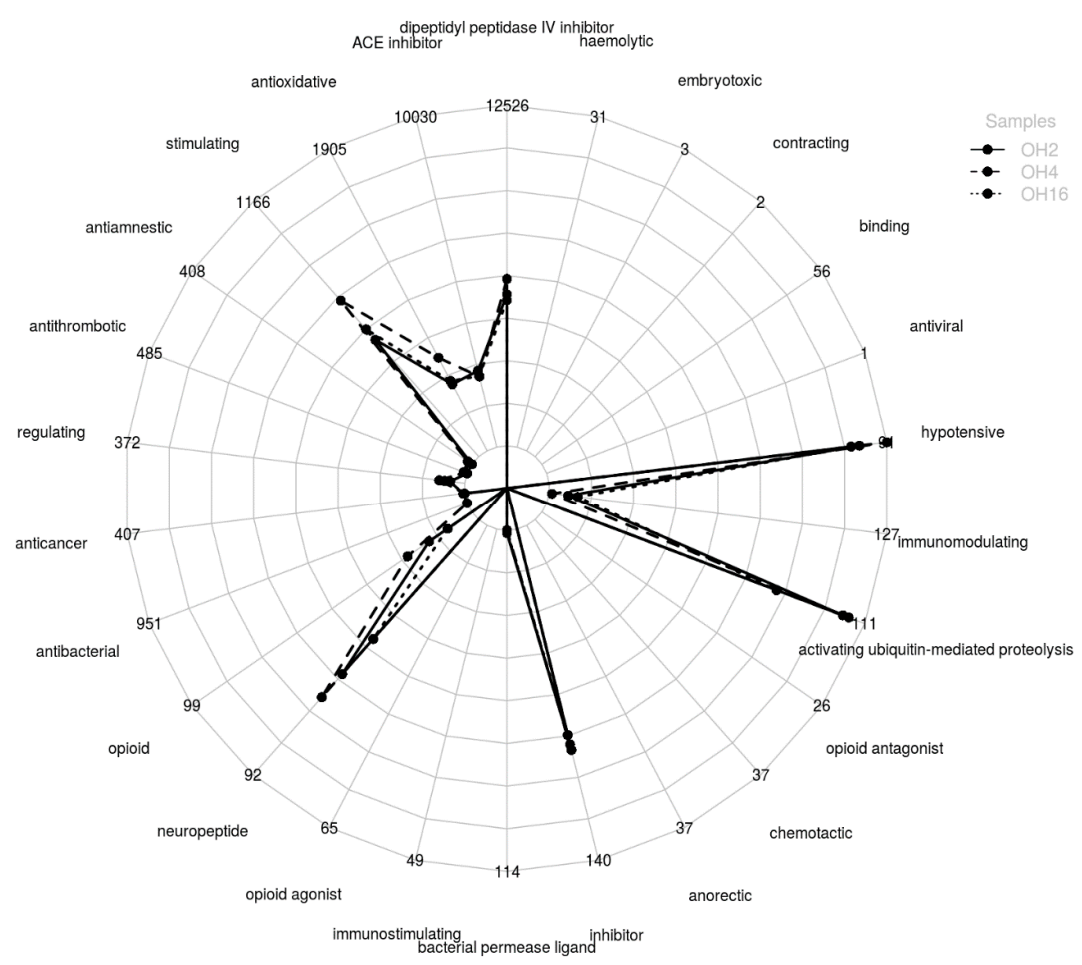

Figure 5. Quantification of potential bioactive peptides in ovalbumin total hydrolysates using Cynara scolymus water-soluble extract at different hydrolysis times: $2 \mathrm{~h}(\mathrm{OH} 2), 4 \mathrm{~h}(\mathrm{OH} 4)$, and $16 \mathrm{~h}(\mathrm{OH} 16)$, considering their peptide spectral matches (PSMs) in liquid chromatography mass spectrometry and taking into account the presence of demonstrated bioactive sequences in their primary structure. The identified peptides and their respective quantification for each sample were extracted. The quantification values were normalized according to the total PSM of all peptides in the samples. In this way, quantification of the same peptide between samples was comparable. ACE = angiotensin I-converting enzyme. 


\section{Discussion}

\subsection{Total Peptides and Hydrophilic and Hydrophobic Peptides of Ovalbumin Hydrolysates}

Our results are consistent with several studies on egg white protein hydrolysates, where the degree of hydrolysis increased with hydrolysis time, using both enzymes of plant origin, such as papain [34,35], as well as digestive enzymes of animal origin $[25,34,36]$, microbial origin (such as alcalase, neutrase, and thermolysin) $[34,37,38]$, or fungal origin (Flavourzyme) [34].

No studies have been found regarding the total concentration and proportion of hydrophobic and hydrophilic peptides in egg white hydrolysates. However, some publications have reported the amino acid composition of the hydrolysates and, occasionally, their percentages of hydrophobic amino acids [16,39-41]. Normally, the content of hydrophobic amino acids and their hydrophobic value determines the hydrophobicity of the hydrolysates [16]. The $\mathrm{OH} 2$ presented a hydrophobic peptide concentration of $80.02 \pm 5.64 \%$ in the TH and of $72.83 \pm 1.91 \%$ in its fraction $<3 \mathrm{kDa}$. These values are higher than those indicated in different studies on egg white protein hydrolysates. Thus, Ren et al. (2014a) obtained $48.51 \%$ of hydrophobic amino acids in a duck egg white hydrolysate, elaborated with an enzymatic combination, with a specific hydrolase for egg protein and alcalase [16]. Sun et al. (2014) reported $43.23 \%$ of hydrophobic amino acids in the 2-5 $\mathrm{kDa}$ fraction of an egg white hydrolysate made with pepsin [40]. Liu et al. (2015) determined $42.76 \%$ of hydrophobic amino acids in the $<1 \mathrm{kDa}$ fraction of an egg white hydrolysate with alcalase [42]. Chen et al. (2012) obtained percentages of hydrophobic amino acids of 44.93 and $49.28 \%$ for the TH of egg white with pepsin and its fraction $<3 \mathrm{kDa}$, respectively [39]. Chen and Chi (2011) indicated $46.97 \%$ of hydrophobic amino acids in their egg white hydrolysate prepared with papain at the hydrolysis time of three hours [35]. In the same way, You and $\mathrm{Wu}$ (2011) elaborated different hydrolysates from egg white protein with thermolysin, alcalase, and a combination of pepsin and pancreatin at three hours of hydrolysis time, obtaining $44.46 \%, 43.55 \%$, and $44.80 \%$ of hydrophobic amino acids for each of them, respectively [41]. Due to the high proportion of hydrophobic peptides in our hydrolysates, it is expected that they yield high ACE inhibitory, antioxidant, and antimicrobial activity $[19,25,43,44]$.

\subsection{ACE Inhibitory Activity}

The results observed are related to those reported by various authors who observed that there is an optimal degree of hydrolysis in the formation of a high concentration of peptides with ACE inhibitory activity [39,45]. Thus, Chiang et al. (2008) described that after two to four hours of hydrolysis time, the inhibitory activity of ACE was stabilized [38]. Tanzadehpanah et al. (2013) described that, in the first hydrolysis intervals, the ACE inhibitory activity of the hydrolysates rose until achieving its maximum at four hours of hydrolysis [46]. Chen et al. (2012b) obtained a maximum ACE inhibitory activity at five hours of hydrolysis [39], and Quirós et al. (2007) described that the ACE activity of the hydrolysates increased with the hydrolysis time up to eight hours [45].

The $<3 \mathrm{kDa}$ fractions of the hydrolysates showed the greatest inhibition of the ACE. These results are consistent with those observed in other studies, where lower molecular weight peptides were attributed the main ACE inhibitory activity of hydrolysates [25,38].

$\mathrm{OH} 16$ and its fraction $<3 \mathrm{kDa}$ had an $\mathrm{IC}_{50}$ value of $69.55 \pm 3.12 \mu \mathrm{g} / \mathrm{mL}$ and $64.04 \pm$ $0.37 \mu \mathrm{g} / \mathrm{mL}$, respectively. These values are lower (indicating greater activity) than those reported for other ovalbumin hydrolysates using proteases of plant origin. For example, in the hydrolysis of egg white with the commercial protease Promod 144P from Carica papaya, an optimal $\mathrm{IC}_{50}$ of $78.7 \mu \mathrm{g} / \mathrm{mL}$ was obtained at $24 \mathrm{~h}$ of hydrolysis [34]. Pokora et al. (2014) prepared egg white protein hydrolysates with proteases extracted from Cucurbita ficifolia, obtaining an ACE inhibitory activity after five hours of hydrolysis, with an $\mathrm{IC}_{50}$ of $9071 \mu \mathrm{g} / \mathrm{mL}$ [47]. Similarly, Chen and Chi (2011) obtained an egg white protein hydrolysate elaborated with papain at a hydrolysis time of three hours that yielded an $\mathrm{IC}_{50}$ of $1676 \mu \mathrm{g} / \mathrm{mL}$ [35], this concentration being 24 times higher than that observed in $\mathrm{OH} 16$. 
In the same way, several works that used animal or microbial origin proteases obtained less ACE inhibitory activity than that shown by our hydrolysates prepared with artichoke extract. For example, Huang et al. (2015) reported a 70.55\% ACE inhibition in ovalbumin hydrolysates with pepsin at a hydrolysis time of approximately four hours [36]. Abeyrathne et al. (2014) used combinations of alcalase, papain, pepsin, trypsin, and chymotrypsin, obtaining less than $80 \%$ inhibition in all cases [48]. Tanzadehpanah et al. (2013) used trypsin for the production of ostrich egg white hydrolysates, reporting ACE inhibition percentages between 28 and $57 \%$ [46]. In ovalbumin hydrolysates with pepsin obtained at three hours of hydrolysis, an $\mathrm{IC}_{50}$ of $643.1 \mu \mathrm{g} / \mathrm{mL}$ was reported [49], this concentration being about nine times higher than that obtained for OH16. Chen et al. (2012b) observed the highest ACE inhibitory activity (50.61\%) at five hours of hydrolysis of egg white with trypsin [39], using a hydrolysate concentration of $1 \mathrm{mg} / \mathrm{mL}$, eight times higher than that used in our assay $(0.125 \mathrm{mg} / \mathrm{mL})$.

The ovalbumin hydrolysates prepared with Cynara scolymus L. aqueous flower extract, even at short periods of hydrolysis, presented a powerful inhibitory activity of ACE in vitro compared to those described in other studies using other enzymes of plant, animal, and microbial origin, demonstrating the importance of the specificity of the proteinase used in the production of bioactive peptides [50-52]. Thereby, the aspartic proteinases of flowers of various species of the genus Cynara proved to have an elevated proteolytic activity that results in deep fragmentation [53], producing small peptides that are more accessible to the active site of the ACE [54]. Furthermore, our hydrolysates obtained with artichoke flower extract presented a high concentration of hydrophobic peptides, which may explain their greater ACE inhibitory activity [18]. Nevertheless, the influence of the food protein used as a substrate must be taken into account. In fact, in a previous study using the Cynara scolymus enzyme extract over bovine casein, a lower ACE inhibition in the hydrolysates (with an $\mathrm{IC}_{50}$ of $114.21 \mu \mathrm{g} / \mathrm{mL}$ at a hydrolysis time of $16 \mathrm{~h}$ ) than that showed by ovalbumin hydrolysates was obtained, which suggests that the hydrolysis of ovalbumin with cynarases yields peptides with greater potential antihypertensive activity than those obtained from bovine casein [30].

\subsection{Antioxidant Activity}

Antioxidant peptides from eggs could avoid oxidative harm through numerous routes, such as free radical scavenging, chelating pro-oxidative transition metal ions, inactivation of reactive oxygen species, and reducing hydroperoxides $[4,55,56]$, and therefore, it is necessary to evaluate their antioxidant activity with different assays.

Several studies with egg white protein hydrolysates reported a dose-dependent DPPH RSA, increasing this activity with the hydrolysate concentration [35,39,57]. According to TEAC values, OH2 showed the most powerful DPPH RSA. This may be due to the fact that the greater amount of aromatic and hydrophobic amino acid residues in the peptides could grant greater antioxidant power to the hydrolysates, since these amino acids supply hydrogen to the reactive oxygen species [44]. OH2 was precisely the hydrolysate that presented the highest ratio of hydrophobic peptides. From this point of view, in antioxidant capacity tests with fat-soluble systems, such as the DPPH radical one, the hydrophobicity of the peptides is a relevant point in the free radical scavenging activity [58]. The molecular weight of the peptides also significantly affected the DPPH RSA. Similarly, Chen et al. (2012a) described better activity in the fraction $<3 \mathrm{kDa}(78.74 \%)$ than in the total $(73.14 \%)$ of egg white protein hydrolysates prepared with papain during three hours of hydrolysis at $5 \mathrm{mg} / \mathrm{mL}$ [57], this concentration being about five times higher than that used in our assays. Our results also showed greater activity against DPPH than those reported for the fraction $<1 \mathrm{kDa}$ of an alcalase egg white protein hydrolysate with a $39.51 \%$ RSA [42]. The ovalbumin hydrolysates elaborated with Cynara scolymus extract showed a significantly higher DPPH RSA $(p<0.01)$ than those obtained from bovine casein, both in TH and $<3 \mathrm{kDa}$ fractions $(30.89 \%$ and $25.67 \%$, respectively, in casein hydrolysates vs. $72.51 \%$ and $74.09 \%$, respectively, in ovalbumin hydrolysates) [30]. 
The ovalbumin hydrolysates produced with proteases extracted from the artichoke flower displayed a powerful antioxidant activity against the ABTS radical. Thus, OH16 gave an $\mathrm{IC}_{50}$ value $(6.92 \pm 0.14 \mu \mathrm{g} / \mathrm{mL})$ about 51 times lower (indicating greater activity) than that reported for a hydrolyzed ostrich egg white with pepsin and pancreatin $(0.36 \mathrm{mg} / \mathrm{mL})$ [59]. In the same way, Noh and Suh (2015) described the decrease in IC $_{50}$ with hydrolysis time in liquid egg white hydrolysates prepared with alcalase, achieving the lowest $\mathrm{IC}_{50}$ value at $32 \mathrm{~h}$ of hydrolysis time $(0.84 \mathrm{mg} / \mathrm{mL})$ [60], this concentration being approximately 120 times higher than that showed by OH16 with artichoke flower extract. On the other hand, taking into consideration the activity of the artichoke extract in other food matrices, in the case of $\mathrm{ABTS}^{+} \mathrm{RSA}$, there were no statistically significant differences between the ovalbumin hydrolysates and the bovine casein at the same hydrolysis times $(p>0.05)[30]$.

The ovalbumin hydrolysates with artichoke flower extract showed an iron (II) chelating activity more potent than that described by Baratzadeh et al. (2013) for two peptides purified from goose egg white protein hydrolysate with papain, yielding an $\mathrm{IC}_{50}>100 \mu \mathrm{g} / \mathrm{mL}$ [61]. In addition, comparing the activity of the artichoke extract to bovine casein, there was a significantly lower iron (II) chelating activity in this substrate $(p<0.01)$ in both the TH and $<3 \mathrm{kDa}$ fraction of the hydrolysates at the same hydrolysis time ( $16 \mathrm{~h}$ ), showing that the casein hydrolysates had an $\mathrm{IC}_{50}$ value much higher $(337.09 \mu \mathrm{g} / \mathrm{mL}$ in the $\mathrm{TH}$, and $221.49 \mu \mathrm{g} / \mathrm{mL}$ in its $<3 \mathrm{kDa}$ fraction) [30].

The ovalbumin hydrolysates produced with artichoke flower extract proteases showed great differences between the different antioxidant activity tests. The activity of the hydrolysates against the DPPH radical was substantially lower than that shown in the inhibition of the ABTS radical, with TEAC values of $\mu \mathrm{M}$ of Trolox $/ \mathrm{mg}$ vs. $\mathrm{mM}$ of Trolox $/ \mathrm{mg}$, respectively. These results are similar to those obtained in other works with enzymatic hydrolysates of egg white protein $[37,42,60]$. This difference is probably due to the distinct solubility and diffusion of the radicals used [62]. DPPH, being a fat-soluble compound despite being dissolved in alcohol, may not disperse well to the target peptides in an aqueous solution, thus, its interaction could be restricted. On the contrary, radical species soluble in water, such as $\mathrm{ABTS}^{+}$, could be more accessible to peptides in an aqueous solution, and thus react more efficiently with the peptides of hydrolysates [60]. In addition, with the longer hydrolysis time, a higher amount of amino acids and small peptides are produced, which are hydrophilic, and therefore accomplish the scavenging reaction more easily with the ABTS radical than with DPPH [62]. Thus, we have seen that the activity of our hydrolysates against the ABTS radical increased with the hydrolysis time, exactly the opposite of what happened when it was against the DPPH radical. However, the importance of hydrophobic amino acids in free radical scavenging has been described [63], so that peptides with an elevated amount of hydrophobic amino acids could raise the antioxidant activity of hydrolysates. In this sense, the two-hour hydrolysate, with the highest ratio of $\mathrm{OH} / \mathrm{HI}$ peptides, yielded better iron chelating and DPPH radical scavenging activity.

\subsection{Antimicrobial Activity}

Not many studies have been found in the literature about antimicrobial activity in hydrolysates of ovalbumin of chicken egg white or other poultry species. Most of the studies found on antimicrobial activity in egg hydrolysates are based on the hydrolysis of lysozyme from egg white. Lysozyme is an enzyme that has demonstrated antimicrobial activity by itself, being capable of hydrolyzing the $\beta$ bonds between $\mathrm{N}$-acetylneuramic acid and N-acetyl glucosamine of bacterial walls [64]. Memarpoor-Yazdi et al. (2012) isolated the NTDGSTDYGILQINSR peptide from the hydrolysis of hen egg white lysozyme with an enzymatic combination of papain and trypsin. This peptide showed antibacterial activity against E. coli and L. mesenteroides [65]. Furthermore, Thammasirirak et al. (2010) isolated the TAKPEGLSY peptide from the hydrolysis of goose egg white lysozyme with pepsin and trypsin, which was shown to have activity against $V$. cholerae and S. epidermidis [66]. Similarly, Mine et al. (2004) isolated two antimicrobial peptides from hen egg white 
lysozyme by digestion with pepsin and trypsin, IVSDGDMNAW and HGLDNYR, with activity against E. coli K-12 and Staphylococcus aureus 23-394 [67]. On the other hand, Tang et al. (2013) described antimicrobial activity in different ovalbumin hydrolysates obtained with pepsin, trypsin, and papain at determined hydrolysis times, since the same enzyme, depending on the time it was allowed to act on the substrate, could give rise to peptides, which, instead of inhibiting, enhanced the growth of the microorganism. In this same study, in the case of ovalbumin hydrolysates obtained with Flavourzyme ${ }^{\circledR}$, neutrase, and alcalase, at any of the different hydrolysis times tested (one, two, three, four, and five hours), the growth of E. coli was promoted, which could indicate that the hydrolysis time, which affects the degree of cleavage of the peptide chain, or the specificity of certain enzymes, can provide the hydrolysate with nutrients that stimulate the growth of the microorganism [68]. Regarding the enzymatic artichoke extract activity producing bovine casein hydrolysates, we obtained peptides that gave similar antimicrobial results to those obtained with the ovalbumin hydrolysates, showing only a slight inhibition on the growing of E. faecalis, increasing its Lag phase and lowering its maximum growth, but having no influence in the other microorganisms tested [30].

\subsection{Peptide Identification}

A large number of peptides with multiple in vitro biological activities have also been identified from egg white protein. For example, WESLSRLLG peptide obtained from the hydrolysis of ostrich egg white protein with pepsin and pancreatin demonstrated free radical scavenging activity and ACE inhibition ( $\mathrm{IC}_{50}: 47.6 \mu \mathrm{g} / \mathrm{mL}$ ) [69]; the peptides FRADHPFL, RADHPFL, YAEERYPIL, YRGGLEPINF, ESIINF, RDILNQ, IVF, YQIGL, SALAM, and FSL, obtained from the hydrolysis of hen egg white with pepsin, have shown ACE inhibition, as well as antioxidant, vasodilator, and antihypertensive activity [34]; DHTKE, FFGFN, and MPDAHL, from the hydrolysis of egg white protein with alkaline, demonstrated antioxidant activity [42]. YAEERYPIL sequence was identified in the egg white hydrolysate with pepsin [34] and, precisely, this ACE inhibitor peptide has also been identified in the ovalbumin hydrolysates with artichoke flower extract.

\section{Conclusions}

Ovalbumin peptides obtained from extracts of $C$. scolymus demonstrated an elevated level of ACE inhibition and antioxidant activity in vitro compared with the findings of similar studies using enzymes of different origins (vegetable, animal, or bacterial). However, the hydrolysates did not show antibacterial activity in vitro. The hydrolysis time of $16 \mathrm{~h}$ yielded hydrolysates with a greater concentration of peptides. The hydrolysate obtained at a hydrolysis time of two hours showed a higher concentration of hydrophobic peptides, its low molecular weight fraction of $<3 \mathrm{kDa}$ being the sample that demonstrated a greater level of ACE inhibition, DPPH radical scavenging activity, and iron (II) chelating activity. We identified the sequence of four bioactive peptides that demonstrated antioxidant and ACE inhibition activities. We also identified a large number of peptides with putative activity and that possessed fragments of bioactive sequences, particularly sequences related to antioxidant activity, hypotensive activity, and inhibition of dipeptidyl peptidase IV.

Author Contributions: Conceptualization, A.A. and L.T.; Data curation, E.B.-G., A.A., and L.T.; Formal analysis, E.B.-G., A.A., F.G.-R., and L.T.; Funding acquisition, L.T.; Investigation, E.B.-G., A.A., F.G.-R., J.M.C., and L.T.; Methodology, E.B.-G., A.A., F.G.-R., J.M.C., and L.T.; Project administration, L.T.; Software, E.B.-G., F.G.-R., and L.T.; Supervision, A.A., J.M.C., and L.T.; Writing-original draft, E.B.-G.; Writing-review \& editing, E.B.-G., A.A. and L.T. All authors have read and agreed to the published version of the manuscript.

Funding: This research received no external funding.

Institutional Review Board Statement: Not applicable.

Informed Consent Statement: Not applicable. 
Data Availability Statement: Data is contained within this article.

Acknowledgments: The authors thank UCAM Universidad Católica de Murcia (Spain) for their financial support for the project (PMAFI-01/12). The authors acknowledge Carlos Fuentes and Francisco Amil from the Proteomic and Bioinformatics departments of the Universidad de Córdoba (Spain) for their valuable assistance.

Conflicts of Interest: The authors declare no conflict of interest.

\section{References}

1. Miranda, J.M.; Anton, X.; Redondo-Valbuena, C.; Roca-Saavedra, P.; Rodriguez, J.A.; Lamas, A.; Franco, C.M.; Cepeda, A. Egg and egg-derived foods: Effects on human health and use as functional foods. Nutrients 2015, 7, 706-729. [CrossRef] [PubMed]

2. Martinez-Villaluenga, C.; Peñas, E.; Frias, J. Chapter 2-Bioactive peptides in fermented foods: Production and evidence for health effects. In Fermented Foods in Health and Disease Prevention; Frias, J., Martinez-Villaluenga, C., Peñas, E., Eds.; Academic Press: Boston, MA, USA, 2017; pp. 23-47. ISBN 978-0-12-802309-9.

3. Zhang, Y.; Duan, X.; Zhuang, Y. Purification and characterization of novel antioxidant peptides from enzymatic hydrolysates of tilapia (Oreochromis niloticus) skin gelatin. Peptides 2012, 38, 13-21. [CrossRef] [PubMed]

4. Zambrowicz, A.; Eckert, E.; Pokora, M.; Bobak, Ł.; Dąbrowska, A.; Szołtysik, M.; Trziszka, T.; Chrzanowska, J. Antioxidant and antidiabetic activities of peptides isolated from a hydrolysate of an egg-yolk protein by-product prepared with a proteinase from Asian pumpkin (Cucurbita ficifolia). RSC Adv. 2015, 5, 10460-10467. [CrossRef]

5. Lee, J.H.; Paik, H.-D. Anticancer and immunomodulatory activity of egg proteins and peptides: A review. Poult. Sci. 2019, 98, 6505-6516. [CrossRef] [PubMed]

6. Lin, S.; Jin, Y.; Liu, M.; Yang, Y.; Zhang, M.; Guo, Y.; Jones, G.; Liu, J.; Yin, Y. Research on the preparation of antioxidant peptides derived from egg white with assisting of high-intensity pulsed electric field. Food Chem. 2013, 139, 300-306. [CrossRef]

7. Chen, G.; Zhang, X.W. Proteomics in Food Biotechnology. In Omics Technologies: Tools for Food Science; Benkeblia, N., Ed.; Crc Press-Taylor \& Francis Group: Boca Raton, FL, USA, 2012; pp. 99-118.

8. Yuan, J.; Zheng, Y.; Wu, Y.; Chen, H.; Tong, P.; Gao, J. Double enzyme hydrolysis for producing antioxidant peptide from egg white: Optimization, evaluation, and potential allergenicity. J. Food Biochem. 2020, 44, e13113. [CrossRef]

9. Zhang, B.; Wang, H.; Wang, Y.; Yu, Y.; Liu, J.; Liu, B.; Zhang, T. Identification of antioxidant peptides derived from egg-white protein and its protective effects on $\mathrm{H}_{2} \mathrm{O}_{2}$-induced cell damage. Int. J. Food Sci. 2019, 54, 2219-2227. [CrossRef]

10. Benedé, S.; Molina, E. Chicken egg proteins and derived peptides with antioxidant properties. Foods 2020, 9, 735. [CrossRef]

11. Llorente, B.E.; Brutti, C.B.; Caffini, N.O. Purification and characterization of a milk-clotting aspartic proteinase from globe artichoke (Cynara scolymus L.). J. Agric. Food Chem. 2004, 52, 8182-8189. [CrossRef]

12. Sidrach, L.; Garciacanovas, F.; Tudela, J.; Neptunorodriguezlopez, J. Purification of cynarases from artichoke (Cynara scolymus L.): Enzymatic properties of cynarase A. Phytochemistry 2005, 66, 41-49. [CrossRef]

13. Tejada, L.; Abellán, A.; Cayuela, J.M.; Martínez-Cacha, A.; Fernández-Salguero, J. Proteolysis in goats' milk cheese made with calf rennet and plant coagulant. Int. Dairy J. 2008, 18, 139-146. [CrossRef]

14. Agboola, S.; Chen, S.; Zhao, J. Formation of bitter peptides during ripening of ovine milk cheese made with different coagulants. Int. J. Dairy Technol. 2004, 84, 567-578. [CrossRef]

15. Bueno-Gavilá, E. Utilización de Proteasas de Cynara Scolymus L. para la Obtención de Péptidos Bioactivos a partir de Ovoalbúmina, Caseina y leche; Universidad Católica de Murcia (UCAM): Murcia, Spain, 2017.

16. Ren, J.; Zhao, M.; Shi, J.; Wang, J.; Jiang, Y.; Cui, C.; Kakuda, Y.; Xue, S.J. Purification and identification of antioxidant peptides from grass carp muscle hydrolysates by consecutive chromatography and electrospray ionization-mass spectrometry. Food Chem. 2008, 108, 727-736. [CrossRef] [PubMed]

17. Udenigwe, C.C.; Aluko, R.E. Food protein-derived bioactive peptides: Production, processing, and potential health benefits. J. Food Sci. 2012, 77, R11-R24. [CrossRef] [PubMed]

18. Cheung, H.S.; Wang, F.L.; Ondetti, M.A.; Sabo, E.F.; Cushman, D.W. Binding of peptide substrates and inhibitors of angiotensinconverting enzyme. Importance of the COOH-terminal dipeptide sequence. J. Biol. Chem. 1980, 255, 401-407. [CrossRef]

19. Nguyen, L.T.; Haney, E.F.; Vogel, H.J. The expanding scope of antimicrobial peptide structures and their modes of action. Trends Biotechnol. 2011, 29, 464-472. [CrossRef]

20. Minkiewicz, P.; Dziuba, J.; Iwaniak, A.; Dziuba, M.; Darewicz, M. BIOPEP database and other programs for processing bioactive peptide sequences. J. AOAC Int. 2008, 91, 965-980. [CrossRef]

21. Fernández-Salguero, J.; Tejada, L.; Gómez, R. Use of powdered vegetable coagulant in the manufacture of ewe's milk cheeses: Cheese-making with a powdered vegetable coagulant. J. Sci. Food Agric. 2002, 82, 464-468. [CrossRef]

22. Association of Analytical Chemists. Official Methods of Analysis; Association of Analytical Chemists: Arlington, VA, USA, 1990.

23. González de Llano, D.; Polo, M.C.; Ramos, M. Study of proteolysis in artisanal cheeses: High performance liquid chromatography of peptides. J. Dairy Sci. 1994, 78, 1018-1024. [CrossRef]

24. Cushman, D.W.; Cheung, H.S. Spectrophotometric assay and properties of the angiotensin-converting enzyme of rabbit lung. Biochem. Pharmacol. 1971, 20, 1637-1648. [CrossRef] 
25. Miguel, M.; Recio, I.; Gómez-Ruiz, J.A.; Ramos, M.; López-Fandiño, R. Angiotensin I-converting enzyme inhibitory activity of peptides derived from egg white proteins by enzymatic hydrolysis. J. Food Prot. 2004, 67, 1914-1920. [CrossRef] [PubMed]

26. Bersuder, P.; Hole, M.; Smith, G. Antioxidants from heated histidine-glucose model system. I: Investigation of the antioxidant role of histidine and isolation of antioxidants by high-performance liquid chromatography. J. Am. Oil Chem. Soc. 1998, 75, 181-187. [CrossRef]

27. De Gobba, C.; Espejo-Carpio, F.J.; Skibsted, L.H.; Otte, J. Antioxidant peptides from goat milk protein fractions hydrolysed by two commercial proteases. Int. Dairy J. 2014, 39, 28-40. [CrossRef]

28. Wu, C.-R.; Huang, M.-Y.; Lin, Y.-T.; Ju, H.-Y.; Ching, H. Antioxidant properties of Cortex Fraxini and its simple coumarins. Food Chem. 2007, 104, 1464-1471. [CrossRef]

29. Hill, L.E.; Gomes, C.; Taylor, T.M. Characterization of beta-cyclodextrin inclusion complexes containing essential oils (transcinnamaldehyde, eugenol, cinnamon bark, and clove bud extracts) for antimicrobial delivery applications. LWT-Food Sci. Technol. 2013, 51, 86-93. [CrossRef]

30. Bueno-Gavilá, E.; Abellán, A.; Girón-Rodríguez, F.; Cayuela, J.M.; Salazar, E.; Gómez, R.; Tejada, L. Bioactivity of hydrolysates obtained from bovine casein using artichoke (Cynara scolymus L.) proteases. J. Dairy Sci. 2019, 102, 10711-10723. [CrossRef] [PubMed]

31. Shen, S.; Chahal, B.; Majumder, K.; You, S.-J.; Wu, J. Identification of novel antioxidative peptides derived from a thermolytic hydrolysate of ovotransferrin by LC-MS/MS. J. Agric. Food Chem. 2010, 58, 7664-7672. [CrossRef]

32. Konrad, B.; Anna, D.; Marek, S.; Marta, P.; Aleksandra, Z.; Józefa, C. The evaluation of dipeptidyl peptidase (DPP)-IV, $\alpha-$ glucosidase and angiotensin converting enzyme (ACE) inhibitory activities of whey proteins hydrolyzed with serine protease isolated from asian pumpkin (Cucurbita ficifolia). Int. J. Pept. Res. Ther. 2014, 20, 483-491. [CrossRef]

33. Duan, X.; Wu, F.; Li, M.; Yang, N.; Wu, C.; Jin, Y.; Yang, J.; Jin, Z.; Xu, X. Naturally occurring angiotensin I-converting enzyme inhibitory peptide from a fertilized egg and its inhibitory mechanism. J. Agric. Food Chem. 2014, 62, 5500-5506. [CrossRef]

34. Garcés-Rimón, M.; López-Expósito, I.; López-Fandiño, R.; Miguel, M. Egg white hydrolysates with in vitro biological multiactivities to control complications associated with the metabolic syndrome. Eur. Food Res. Technol. 2016, 242, 61-69. [CrossRef]

35. Chen, C.; Chi, Y.-J. Antioxidant, ACE inhibitory activities and functional properties of egg white protein hydrolysate. J. Food Biochem. 2011, 36, 383-394. [CrossRef]

36. Huang, Q.; Li, S.; Teng, H.; Jin, Y.; Ma, M.; Song, H. Optimizing preparation conditions for angiotensin-I-converting enzyme inhibitory peptides derived from enzymatic hydrolysates of ovalbumin. Food Sci. Biotechnol. 2015, 24, 2193-2198. [CrossRef]

37. Jakovetić, S.; Luković, N.; Jugović, B.; Gvozdenović, M.; Grbavčić, S.; Jovanović, J.; Knežević-Jugović, Z. Production of antioxidant egg white hydrolysates in a continuous stirred tank enzyme reactor coupled with membrane separation unit. Food Bioprocess Technol. 2015, 8, 287-300. [CrossRef]

38. Chiang, W.-D.; Tsou, M.-J.; Weng, C.-H.; Tsai, T.-C. Production of angiotensin I-converting enzyme inhibitor derived from egg white protein hydrolysates using a membrane reactor. J. Food Drug Anal. 2008, 16, 54-60. [CrossRef]

39. Chen, C.; Chi, Y.-J.; Zhao, M.-Y.; Xu, W. Influence of degree of hydrolysis on functional properties, antioxidant and ACE inhibitory activities of egg white protein hydrolysate. Food Sci. Biotechnol. 2012, 21, 27-34. [CrossRef]

40. Sun, S.; Niu, H.; Yang, T.; Lin, Q.; Luo, F.; Ma, M. Antioxidant and anti-fatigue activities of egg white peptides prepared by pepsin digestion: Antioxidant and anti-fatigue activities of egg white peptides. J. Sci. Food Agric. 2014, 94, 3195-3200. [CrossRef]

41. You, S.-J.; Wu, J. Angiotensin-I Converting Enzyme Inhibitory and Antioxidant Activities of Egg Protein Hydrolysates Produced with Gastrointestinal and Nongastrointestinal Enzymes. J. Food Sci. 2011, 76, C801-C807. [CrossRef]

42. Liu, J.; Jin, Y.; Lin, S.; Jones, G.S.; Chen, F. Purification and identification of novel antioxidant peptides from egg white protein and their antioxidant activities. Food Chem. 2015, 175, 258-266. [CrossRef]

43. Kobayashi, Y.; Yamauchi, T.; Katsuda, T.; Yamaji, H.; Katoh, S. Angiotensin-I converting enzyme (ACE) inhibitory mechanism of tripeptides containing aromatic residues. J. Biosci. Bioeng. 2008, 106, 310-312. [CrossRef]

44. Guo, H.; Kouzuma, Y.; Yonekura, M. Structures and properties of antioxidative peptides derived from royal jelly protein. Food Chem. 2009, 113, 238-245. [CrossRef]

45. Quirós, A.; Chichón, R.; Recio, I.; López-Fandiño, R. The use of high hydrostatic pressure to promote the proteolysis and release of bioactive peptides from ovalbumin. Food Chem. 2007, 104, 1734-1739. [CrossRef]

46. Tanzadehpanah, H.; Asoodeh, A.; Saberi, M.R.; Chamani, J. Identification of a novel angiotensin-I converting enzyme inhibitory peptide from ostrich egg white and studying its interactions with the enzyme. Innov. Food Sci. Emerg. Technol. 2013, 18, 212-219. [CrossRef]

47. Pokora, M.; Zambrowicz, A.; Dąbrowska, A.; Eckert, E.; Setner, B.; Szołtysik, M.; Szewczuk, Z.; Zabłocka, A.; Polanowski, A.; Trziszka, T.; et al. An attractive way of egg white protein by-product use for producing of novel anti-hypertensive peptides. Food Chem. 2014, 151, 500-505. [CrossRef] [PubMed]

48. Abeyrathne, E.D.N.S.; Lee, H.Y.; Jo, C.; Nam, K.C.; Ahn, D.U. Enzymatic hydrolysis of ovalbumin and the functional properties of the hydrolysates. Poult. Sci. 2014, 93, 2678-2686. [CrossRef]

49. Zambrowicz, A.; Timmer, M.; Eckert, E.; Trziszka, T. Evaluation of the ACE-Inhibitory Activity of Egg-White Proteins Degraded with Pepsin. Pol. J. Food Nutr. Sci. 2013, 63. [CrossRef]

50. Abubakar, A.; Saito, T.; Kitazawa, H.; Kawai, Y.; Itoh, T. Structural analysis of new antihypertensive peptides derived from cheese whey protein by proteinase K digestion. J. Dairy Sci. 1998, 81, 3131-3138. [CrossRef] 
51. Mullally, M.M.; Meisel, H.; FitzGerald, R.J. Angiotensin-I-converting enzyme inhibitory activities of gastric and pancreatic proteinase digests of whey proteins. Int. Dairy J. 1997, 7, 299-303. [CrossRef]

52. Mullally, M.M.; Meisel, H.; FitzGerald, R.J. Identification of a novel angiotensin-I-converting enzyme inhibitory peptide corresponding to a tryptic fragment of bovine $\beta$-lactoglobulin. FEBS Lett. 1997, 402, 99-101. [CrossRef]

53. Galán, E.; Prados, F.; Pino, A.; Tejada, L.; Fernández-Salguero, J. Influence of different amounts of vegetable coagulant from cardoon Cynara cardunculus and calf rennet on the proteolysis and sensory characteristics of cheeses made with sheep milk. Int. Dairy J. 2008, 18, 93-98. [CrossRef]

54. Natesh, R.; Schwager, S.L.U.; Sturrock, E.D.; Acharya, K.R. Crystal structure of the human angiotensin-converting enzymelisinopril complex. Nature 2003, 421, 551-554. [CrossRef]

55. Lee, D.; Bamdad, F.; Khey, K.; Sunwoo, H.H. Antioxidant and anti-inflammatory properties of chicken egg vitelline membrane hydrolysates. Poult. Sci. 2017, 96, 3510-3516. [CrossRef] [PubMed]

56. Lozano-Ojalvo, D.; Molina, E.; López-Fandiño, R. Regulation of exacerbated immune responses in human peripheral blood cells by hydrolysed egg white proteins. PLoS ONE 2016, 11. [CrossRef]

57. Chen, C.; Chi, Y.-J.; Zhao, M.-Y.; Lv, L. Purification and identification of antioxidant peptides from egg white protein hydrolysate. Amino Acids 2012, 43, 457-466. [CrossRef] [PubMed]

58. Chen, H.; Muramoto, K.; Yamauchi, F.; Fujimoto, K.; Nokihara, K. Antioxidative properties of histidine-containing peptides designed from peptides fragments found in the digests of a soybean protein. J. Agric. Food Chem. 1998, 46, 49-53. [CrossRef] [PubMed]

59. Homayouni-Tabrizi, M.; Asoodeh, A.; Abbaszadegan, M.-R.; Shahrokhabadi, K.; Nakhaie Moghaddam, M. An identified antioxidant peptide obtained from ostrich (Struthio camelus) egg white protein hydrolysate shows wound healing properties. Pharm. Biol. 2015, 53, 1155-1162. [CrossRef] [PubMed]

60. Noh, D.O.; Suh, H.J. Preparation of egg white liquid hydrolysate (ELH) and its radical-scavenging activity. Prev. Nutr. Food Sci. 2015, 20, 183-189. [CrossRef] [PubMed]

61. Baratzadeh, M.-H.; Asoodeh, A.; Chamani, J. Antioxidant peptides obtained from goose egg white proteins by enzymatic hydrolysis. Int. J. Food Sci. 2013, 48, 1603-1609. [CrossRef]

62. Zhu, L.; Chen, J.; Tang, X.; Xiong, Y.L. Reducing, Radical Scavenging, and Chelation Properties of in Vitro Digests of AlcalaseTreated Zein Hydrolysate. J. Agric. Food Chem. 2008, 56, 2714-2721. [CrossRef] [PubMed]

63. Chen, H.; Yamauchi, F.; Nokihara, K. Antioxidant activity of designed peptides based on the antioxidative peptide isolated from digests of a soybean protein. J. Agric. Food Chem. 1996, 44, 2619-2623. [CrossRef]

64. Yu, Z.; Yin, Y.; Zhao, W.; Chen, F.; Liu, J. Application and bioactive properties of proteins and peptides derived from hen eggs: Opportunities and challenges: Application of proteins and peptides from hen eggs. J. Sci. Food Agric. 2014, 94, 2839-2845. [CrossRef] [PubMed]

65. Memarpoor-Yazdi, M.; Asoodeh, A.; Chamani, J. A novel antioxidant and antimicrobial peptide from hen egg white lysozyme hydrolysates. J. Funct. Foods 2012, 4, 278-286. [CrossRef]

66. Thammasirirak, S.; Pukcothanung, Y.; Preecharram, S.; Daduang, S.; Patramanon, R.; Fukamizo, T.; Araki, T. Antimicrobial peptides derived from goose egg white lysozyme. Comp. Biochem. Physiol. C Toxicol. Pharmacol. 2010, 151, 84-91. [CrossRef] [PubMed]

67. Mine, Y.; Ma, F.; Lauriau, S. Antimicrobial peptides released by enzymatic hydrolysis of hen egg white lysozyme. J. Agric. Food Chem. 2004, 52, 1088-1094. [CrossRef] [PubMed]

68. Tang, W.; Zhang, H.; Wang, L.; Qian, H. Antimicrobial peptide isolated from ovalbumin hydrolysate by immobilized liposomebinding extraction. Eur. Food Res. Technol. 2013, 237, 591-600. [CrossRef]

69. Asoodeh, A.; Homayouni-Tabrizi, M.; Shabestarian, H.; Emtenani, S.; Emtenani, S. Biochemical characterization of a novel antioxidant and angiotensin I-converting enzyme inhibitory peptide from Struthio camelus egg white protein hydrolysis. J. Food Drug Anal. 2016, 24, 332-342. [CrossRef] [PubMed] 